\title{
HUBUNGAN STIMULASI ORANG TUA DENGAN PERKEMBANGAN ANAK USIA PRASEKOLAH SELAMA PANDEMI COVID
}

\author{
Rahmawati Maulidia ${ }^{1}$, Lilla Maria ${ }^{2}$, Ach Dafir Firdaus ${ }^{3}$ \\ STIKes Maharani Malang \\ Email: rahmawatimaulidia61@gmail.com
}

\begin{abstract}
The Covid-19 pandemic is the first and main health crisis that will occur in the world in 2020. This has led to policies from the Indonesian government, ranging from social distancing to changing physical distancing which has an impact on the online learning system. So the role of parents is very important in providing stimulation to children during online learning methods. The purpose of this study was to determine the relationship between parental stimulation and the development of preschool children during the Covid-19 pandemic. This study used a correlational analytic design with a crosssectional approach in order to determine the relationship between early stimulation of parents and the development of preschool children during the Pandemic Covid-19 at Insan Permata Kindergarten, Malang City. The research sample consisted of all students of TK A and B TK Insan Permata 150 students. The sampling technique used total sampling. The independent variable was parental stimulation and the dependent variable was the development of preschool children. The instrument used was KPSP in google form which can be accessed used mobile online and the data is analyzed using SPSS Windows 7. The statistical results using the Spearman correlation test show that the $p$ value $=0.203$ ( $p$ value $>0.05$ ), that means there is no relationship between parental stimulation and the development of preschool-aged children during the COVID-19 pandemic. The development of preschool children during the Pandemic Covid-19 was influenced by many factors so that a review of the correlation of one factor will be influenced by other factors. This research was expected to provide information to the school in making policies regarding the development of preschool children during the Pandemic Covid-19.
\end{abstract}

Keywords: Stimulation, Parents, Development, Preschool Children, Pandemic Covid-19

\begin{abstract}
Abstrak: Pandemi Covid-19 merupakan krisis kesehatan yang pertama dan utama yang terjadi di dunia dalam tahun 2020. Hal ini memunculkan kebijakan dari pemerintah Indonesia, mulai dari social distancing sampai berganti physical distancing yang berdampak pada sistem pembelajaran dengan metode daring. Sehingga peranan orang tua sangat penting dalam memberikan stimulasi kepada anak selama pembelajaran metode daring. Tujuan dalam penelitian ini untuk mengetahui hubungan stimulasi orang tua dengan perkembangan anak prasekolah selama pandemi Covid-19. Metode penelitian adalah desain analitik korelasional dengan pendekatan cross sectional. Sampel penelitian terdiri dari seluruh siswa TK A dan B TK Insan Permata sejumlah 150 siswa. Teknik sampling menggunakan total sampling. Variabel bebasnya adalah stimulasi orang tua dan variable terikatnya adalah perkembangan anak prasekolah. Instrumen yang digunakan adalah KPSP dalam bentuk google form yang bisa diakses melalui HP secara online dan data dianalisis dengan menggunakan SPSS Windows 7. Hasil statistik dengan menggunakan uji korelasi Spearman menunjukkan bahwa nilai $p$ adalah 0,203 ( $p$ value $>0.05$ ) artinya tidak terdapat hubungan antara stimulasi orang tua dengan perkembangan anak usia prasekolah selama pandemi covid-19. Hal ini dikarenakan perkembangan anak usia prasekolah selama Pandemi Covid-19 dipengaruhi oleh banyak faktor sehingga peninjauan terkait korelasi salah satu faktor akan dipengaruhi oleh faktor yang lainnya. Penelitian ini diharapkan dapat memberikan informasi kepada pihak sekolah dalam pengambilan kebijakan mengenai perkembangan anak prasekolah selama Pandemi Covid-19.
\end{abstract}

Kata kunci: Stimulasi, Orang Tua, Perkembangan, Anak Prasekolah, Pandemi Covid-19

\section{PENDAHULUAN}

Pandemi Covid-19 merupakan krisis kesehatan yang pertama dan utama yang terjadi di dunia dalam tahun 2020. Penyebaran virus covid-19 menyebabkan angka kematian tertinggi di berbagai dunia saat ini sehingga memunculkan berbagai kebijakan yang bertujuan untuk memutus mata rantai penyebaran virus covid-19 termasuk di negara Indonesia. Upaya yang dilakukan pemerintah Indonesia salah satunya dengan melakukan himbauan mulai dari social distancing sampai berganti physical distancing sudah dilakukan. Sehingga dengan adanya pembatasan interaksi tersebut, Kementrian Pendidikan di Indonesia mengeluarkan kebijakan untuk meliburkan sekolah dan mengganti proses kegiatan belajar mengajar dengan menggunakan system dalam jaringan (daring). Pembatasan interaksi ini akan 
mempengaruhi kondisi relasi dan psikologis orang tua terhadap anak maupun sebaliknya. Jika hal ini dibiarkan maka akan mempengaruhi tumbuh kembang anak (Kemensos, 2020).

Apabila Covid-19 ini tidak segera berakhir maka kelompok usia yang bisa terkana dampaknya secara tidak langsung adalah usia anak karena anak-anak merupakan aset masa depan suatu negara. Menurut analisis UNICEF, 99\% anak dan remaja dengan usia $<18$ tahun di seluruh dunia (2,34 miliar) mengalami pembatasan gerak karena harus stay at home. Sedangkan sekitar $60 \%$ usia anak tinggal di salah satu dari 82 negara menjalankan lockdown penuh $7 \%$ dan lockdown sebagian 53\%. Sehingga UNICEF juga meluncurkan adanya agenda globalnya untuk anak-anak yang salah satunya adalah membuat anak agar tetap belajar dan mendukung keluarga untuk memenuhi kebutuhan dan pengasuhan terhadap anak mereka (UNICEF, 2020). Menurut hasil proyeksi Penduduk Indonesia hasil SUPAS 2015 bahwa usia balita merupakan jumlah penduduk terbanyak kedua sekitar 21,9 juta $(27,6 \%)$ dari total penduduk usia 0-17 tahun. Namun hingga saat ini, angka gangguan perkembangan anak masih cukup tinggi. Menurut hasil pemeriksaan yang dilakukan oleh IDAI Jawa Timur dari 2.634 balita kategori usia 0-72 bulan menunjukan hasil bahwa perkembangan normal sesuai dengan usia 53\%, meragukan (membutuhkan pemeriksaan lebih dalam) sebanyak 13\%, dan penyimpangan perkembangan sebanyak 34\% (Nadhiroh F, 2007). Selain itu tingkat pengetahuan orang tua mengenai stimulasi akan mempengaruhi terhadap perkembangan Bahasa balita Usia 0-5 Tahun (Gusti Ayu,2012). Hal ini juga mendapat dukungan bahwa terdapat hubungan antara stimulasi atau pola komunikasi orang tua terhadap perkembangan bahasa balita (Hidayati \& Maslahah, 2013). Hal ini membuktikan masih banyaknya keterlambatan perkembangan yang terjadi pada anak-anak karena kurangnya stimulasi orang tua.

Stimulasi dini yang dilakukan oleh orang tua berdampak pada perkembangan anak usia 5-6 tahun (Ardiana, 2017). Pertumbuhan dan perkembangan yang optimal membutuhkan tidak hanya kecukupan nutrisi namun juga membutuhkan stimulasi yang tepat dimana stimulasi ini merupakan salah satu faktor eksternal yang mempengaruhinya. Bayi dan balita dengan stimulasi yang cukup akan lebih baik perkembangannya daripada balita dengan stimulasi yang kurang atau tidak sama sekali. Semakin stimulasi dilakukan lebih awal dan intensitasnya juga semakin sering dan lama maka akan semakin besar manfaatnya terhadap tumbuh kembang bayi dan balita. Stimulasi sebaiknya dilakukan ketika orang tua melakukan interaksi dengan anaknya misalnya ketika menggendong, mengganti popok, memandikan dan menidurkan (Maryani, 2010). Stimulasi yang baik merupakan salah satu faktor eksternal yang mempengaruhi perkembangan balita. Salah satu faktor yang mempengaruhi perkembangan balita ialah dengan diberikan stimulasi yang baik. Adanya interaksi antara lingkungan dengan rangsangan akan mempengaruhi penyusunan struktur syaraf dalam perkembangan (Suci HF \& Lestari, 2016).

Sehingga dengan melihat sangat pentingnya stimulasi orang tua terhadap tumbuh kembang pada anak prasekolah dan melihat berbagai dampak adanya keterlamabatan tumbuh kembang yang terjadi pada anak dengan kurangnya stimulasi orang tua mendorong peneliti untuk melakukan penelitian tentang Hubungan Stimulasi Dini Orang Tua dengan Perkembangan Anak Usia Prasekolah selama Pandemi Covid-19 di TK Insan Permata Malang. Menurut informasi yang telah didapatkan hampir seluruh anak prasekolah di Kota Malang selama masa study from home, aktivitas di sekolah diliburkan dan diganti dengan melakukan aktivitas di rumah, peneliti beranggapan ini merupakan kesempatan yang sangat bagus untuk melakukan optimalisasi peranan orang tua dalam melakukan stimulasi terhadap anaknya. Sekolah yang nantinya akan kami survey terkait hal ini salah satunya adalah TK Insan Permata yang berada di kota Malang. 


\section{METODE PENELITIAN}

Penelitian ini menggunakan desain analitik korelasional dengan pendekatan crossectional. Populasi penelitian adalah siswa TK A dan TK B Insan Permata Malang sebanyak 150 responden. Sampel penelitian terdiri 150 responden yang terdiri dari TK A dan TK B di TK Insan Permata Malang. Teknik sampling menggunakan Total Sampling. Instrumen yang digunakan dalam penelitian ini adalah dengan menggunakan kuisioner yang mengacu pada stimulasi perkembangan anak usia prasekolah sesuai buku "Pedoman Pelaksanaan Stimulasi, Deteksi dan Intervensi Dini Tumbuh Kembang Anak" dan menggunakan instrument KPSP pada usia 4-6 tahun atau 48-72 bulan dengan pengamatan dari orang tua yang natinya semuanya akan diubah menjadi bentuk google form yang bisa diakses melalui HP secara online. Analisis data menggunakan SPSS Windows 7 dengan uji spearman rank.

\section{HASIL PENELITIAN}

Hasil analisis dari data demografi didapatkan data umum responden berdasarkan usia sebagian besar usia 60-72 bulan sebesar 68 responden (45,3\%), jenis kelamin sebagian besar laki-laki 77 responden (51,3\%). Sedangkan data khusus hasil penelitian didapatkan beberapa grafik diantaranya:

Tabel 1. Karakteristik responden berdasarkan Stimulasi Orang Tua

\begin{tabular}{ccc}
\hline Stimulasi Orang Tua & Frekuensi & Presentase $\%$ \\
\hline Baik & 23 & 15,3 \\
Cukup & 122 & 81,3 \\
Kurang & 5 & 3,4 \\
\hline Jumlah & $\mathbf{1 5 0}$ & $\mathbf{1 0 0 \%}$ \\
\hline
\end{tabular}

Berdasarkan tabel diatas dapat diketahui bahwa sebagian besar stimulasi orang tua kepada anak adalah cukup sebesar 122 responden (81,3\%).

Tabel 2. Karakteristik responden berdasarkan Perkembangan Anak

\begin{tabular}{ccc}
\hline Perkembangan Balita & Frekuensi & Presentase\% \\
\hline Sesuai & 120 & 80 \\
Meragukan & 24 & 16 \\
Penyimpangan & 6 & 4 \\
\hline Total & $\mathbf{1 5 0}$ & $\mathbf{1 0 0 \%}$ \\
\hline
\end{tabular}

Berdasarkan tabel diatas dapat diketahui bahwa perkembangan anak sebagian besar sesuai yaitu 120 responden (80\%). Dari hasil uji statistik menggunakan uji korelasi Spearman Rank dapat diketahui bahwa antara stimulasi orang tua dengan perkembangan anak didapatkan nilai signifikansi sebesar 0,203 $(>0,05)$, yang artinya tidak terdapat hubungan signifikan antara stimulasi orang tua dengan perkembangan anak selama pandemi Covid-19.

\section{PEMBAHASAN}

\section{Stimulasi Orang Tua selama Pandemi Covid-19}

Berdasarkan data yang diperoleh pada bab sebelumnya didapatkan bahwa dari 150 responden TK Insan Permata Kota Malang sebagian besar stimulasi orang tua adalah cukup sebanyak 122 responden (81, $3 \%$ ). Sedangkan sebanyak 23 responden $(15,3 \%)$ stimulasi orang tua baik dan 5 responden $(3,4 \%)$ stimulasi orang tua 
kurang. Stimulasi merupakan hal yang penting dalam tumbuh kembang anak. Anak yang mendapat stimulasi terarah, akan lebih cepat berkembang dibandingkan dengan anak yang kurang atau terlambat mendapatkan stimulasi. Kurangnya stimulasi dapat mengakibatkan keterlambatan perkembangan pada anak. Sebagian besar anak dengan keterlambatan perkembangan tidak teridentifikasi sampai usia prasekolah atau usia sekolah sehingga membuat mereka kesulitan untuk mengembangkan potensi yang di miliki (Grove D, 2015). Stimulasi terhadap tumbuh kembang anak dapat diberikan oleh orang tua maupun anggota keluarga lain dalam kehidupan sehari-hari. Stimulasi yang dilakukan meliputi kemampuan motorik kasar, motoric halus, bicara atau bahasa dan sosialisasi (Depkes RI, 2010).

Orang tua juga berperan sebagai pendidik yang perilakunya pasti akan ditiru dan diikuti oleh anaknya. Pola asuh dan pola didik dalam membesarkan anak dengan baik pasti akan mempengaruhi terhadap perkembangan anak tersebut (Friedman et al, 2010). Oleh karena itu penting bagi orang tua untuk memberikan stimulasi yang optimal dalam mempersiapkan kehidupan anak selanjutnya. Stimulasi yang diberikan juga harus sesuai dengan perkembangan dan karakteristik anak. Stimulasi pada anak usia prasekolah ini bisa dalam bentuk proses pembelajaran. Proses pembelajaran ini harus direncanakan sesuai dengan tahap perkembangan sesuai usia anak. Namun sejak adanya Pandemi Covid-19 semua proses pembelajaran ini mengalami suatu perubahan dan dampak yang luar biasa (Maryani K, 2020).

Pandemi Covid-19 merupakan permasalahan yang terjadi diseluruh dunia. Dampak yang ditimbulkan telah mengubah berbagi aspek kehidupan manusia. Berbagai kebijakan telah dikeluarkan oleh pemerintah dalam rangka mengurangi tingkat penyebaran virus Corona. Salah satu yang terkena dampak adalah pendidikan. Strategi yang digunakan dalam pendidikan terutama pada anak-anak usia dini dan prasekolah antara lain dengan melibatkan orang tua pada stimulasi perkembangannya. Guru di sekolah selaku perencana dan penilai hasil perkembangan anak sementara pendidik di rumah adalah orang tua selaku pelaksana dalam stimulasi pekembangan selama belajar dari rumah (Hewi and Asnawati, 2020).

Berdasarkan hasil penelitian didapatkan data 5 responden $(3,4 \%)$ stimulasi orang tua kurang. Menurut penelitian Azizah, (2012) tentang hubungan stimulasi orang tua dengan perkembangan anak didapatkan adanya stimulasi yang kurang sebesar 48,9 \%. Stimulasi yang kurang ini karena kurang pengetahuan orang tua tentang kebutuhan perkembangan anak sesuai usianya. Selain itu menurut Bornstein (2010), tentang Parenting Knowledge: Experiential and Sociodemographic Factors in European American Mothers of Young Toddlerren menyimpulkan bahwa faktor usia dan pengalaman mempengaruhi terhadap pemberian stimulasi pada anak.

Berdasarkan karakteristik responden menurut pendidikan orang tua, sebagian besar berpendidikan S1 sebanyak 88 responden (58,7\%). Kategori pendidikan formal yang cukup tinggi untuk mengasuh anak dengan pola asuh yang baik. Semakin tinggi pendidikan orang tua maka semakin mudah orang tua mencari pengetahuan atau informasi tentang pemberian stimulus dari berbagai media internet, buku tentang pertumbuhan dan perkembangan anak atau majalah anak. Namun sebagian besar untuk stimulus yang diberikan masuk dalam kategori cukup, banyaknya faktor yang mempengaruhi selain dari konsep pemahaman orang tua terkait cara menstimulus anak juga bisa terlibat. Menurut penelitian Wardani (2020) terkait analisis Kendala orang tua dalam mendampingi Anak belajar di Rumah pada masa Pandemi Covid-19, salah satunya adalah orang tua yang terkadang mengalami kesulitan dalam menumbuhkan minat anak mengikuti stimulus yang diberikan, tidak memiliki waktu yang cukup untuk mendampingi anak dan menstimulasi anak, dan orang tua yang tidak sabar dalam melakukan stimulasi anak.

Menurut peneliti, stimulasi orang tua dalam penelitian ini ada yang baik, cukup dan kurang karena dipengaruhi oleh banyak faktor. Banyak kendala yang dialami orang tua terkait stimulasi anak ketika di rumah yang awalnya stimulasi itu tidak hanya dari orang tua melainkan juga dari guru 
disekolah, namun saat ini hampir sebagian besar dilakukan oleh orang tua. Sehingga butuh waktu penyesuaian dan kerjasama antara kedua pihak dalam melakukan stimulasi yang tepat untuk anak sesuai usianya. Kesiapan orang tua dalam memberikan stimulasi perkembangan baik motorik kasar, motorik halus, sosial dan bahasa selama adanya kebijakan belajar dari rumah sangat menentukan terhadap perkembangan anak di kemudian hari.

\section{Perkembangan Anak Usia Prasekolah selama Pandemi Covid-19}

Berdasarkan hasil survey dengan menggunakan google form KPSP didapatkan bahwa sebagian besar dari 150 responden anak usia prasekolah didapatkan sebanyak 120 (80\%) diketahui memiliki perkembangan yang sesuai. Sedangkan sebanyak 24 responden (16\%) perkembangan anak meragukan dan sebanyak 6 responden (4\%) perkembangan anak terjadi penyimpangan.

Perkembangan adalah bertambahnya kemampuan dalam struktur dan fungsi tubuh yang lebih kompleks dalam pola teratur dan dapat diramalkan, sebagai hasil dari pematangan. Disini menyangkut adanya proses berkembanganya sel-sel tubuh, organ-organ dan sistem organ yang berkembang sehingga masing-masing dapat memenuhi fungsinya. Termasuk juga perkembangan emosi, intelektual dan tingkah laku sebagai hasil interaksi dengan lingkungan (Adriana, D, 2017). Perkembangan terdiri dari perkembangan kognitif, motorik, bahasa, emosi, dan perkembangan perilaku sebagai hasil interaksi dengan lingkungan (Soetjiningsih, 2014).

Menurut penelitian Neuroscience menyatakan bahwa perkembangan otak pada 5 tahun pertama akan lebih cepat, intensif dan sensitif terhadap pengaruh dari eksternal dan lingkungan. Sehingga dengan mengikuti pendidikan usia prasekolah akan memaksimalkan hasil dari proses pembelajaran, tentunya dengan fasilitator yang berkualitas dan terlatih (Guru TK) serta keterlibatan pengasuh utama (orang tua) yang juga berdampak penting. Pendidikan prasekolah akan membantu anak mengembangkan ketrampilan fungsi kognitif, motoric, social dan emosional (Rohman A, 2019).
Hasil penelitian menunjukkan karakteristik responden paling banyak pada usia $60-72$ bulan sebanyak $45,3 \%$ dan usia 48-60 bulan sebanyak 42\%, dimana usia ini termasuk dalam kategori usia prasekolah. Menurut Erik Erikson, tugas perkembangan psikososial anak usia prasekolah termasuk dalam tahap membangun rasa inisiatif vs rasa bersalah, dimana anak usia ini rasa ingin tau nya sangat besar untuk mempelajari hal-hal baru. Anak usia prasekolah ini merasa bangga ketika mampu melakukan kegiatan dengan inisiatifnya sendiri. Anak usia prasekolah ingin mengambangkan dirinya melebihi kemampuannya, kondisi ini dapat menyebabkan dirinya merasa bersalah dan biasanya perkembangan moralnya sudah dapat memahami mana tindakan yang benar dan salah (Rohman A, 2019).

Hasil penelitian menunjukkan sebagian besar dari 150 responden anak usia prasekolah didapatkan sebanyak 120 $(80 \%)$ diketahui memiliki perkembangan mototik kasar, motorik halus, sosial dan bahasa yang sesuai. Perkembangan motorik kasar pada anak usia prasekolah sudah memiliki kontrol yang lebih besar, cenderung gesit dalam berdiri, berjalan, berlari, melompat, naik turun tangga, berjalan maju mundur, berdiri dengan satu kaki, melempar, menangkap, menendang dll. Apabila tidak terpenuhi maka akan mempengaruhi kemampuan dalam ketrampilan motorik halus (misalnya menulis, menggambar dan memotong), karena tanpa ketrampilan motorik kasar yang seimbang maka anak akan banyak berusaha keras untuk melakukan tugas sehari-hari nantinya (childdevelopment, 2019).

Perkembangan sensorik pada anak salah satunya mendorong untuk sosialisasi dimana anak dituntut untuk bisa menjalin koneksi, mengembangkan kemampuan berbicara, belajar bergiliran dan berkolaborasi dengan yang lain. Anak usia 2 hingga 6 tahun mulai mengembangkan kemampuan untuk menghubungkan suara, suku kata dan kata-kata saat berbicara. Anak usia prasekolah dapat memperoleh sebanyak 10-20 kata baru per hari dan pada usia 5 tahun sudah memiliki kosakata 2.100 kata (Taylor et al, 2011).

Hasil penelitian juga menunjukkan sebanyak 24 responden (16\%) 
perkembangan anak meragukan dan sebanyak 6 responden (4\%) perkembangan anak terjadi penyimpangan, namun peneliti tidak melakukan pengkajian lanjutan alasan adanya keraguan dan penyimpangan tersebut. Menurut (Hartanto, 2011) dalam pemantauan perkembangan anak ada beberapa aspek yang dinilai yaitu motorik kasar, motorik halus, bahasa dan personal sosial. Ternyata tidak semua balita dapat berkembang dengan yang ditentukan, malah banyak balita yang perkembangannya tidak sesuai atau terlambat melakukan aktifitas yang seharusnya dilakukan balita seusianya lakukan. Kondisi seperti itu kadang sangat tidak diketahui oleh keluarga, terutama orang tua, biasanya orang tua baru menyadari setelah semuanya terlambat. Maka dari itu, pengetahuan dan pemahaman orang tua tentang tumbuh kembang balita serta memantau dan mendeteksi secara dini apakah anak mengalami gangguan atau keterlambatan dalam perkembangannya seharusnya sudah dimiliki orang tua balita tersebut sejak masih dalam usia dini (Sudirman et.,al, 2016).

Kebutuhan dasar anak meliputi asuh (pangan yaitu kebutuhan gizi, ASI, imunisasi, timbang BB, sandang, papan, kebersihan badan dan lingkungan, pengobatan, olahraga serta rekreasi), asih (emosi dan kasih saying orang tua, rasa aman dan nyaman), dan asah (kebutuhan stimulasi). Ketiga kebutuhan dasar ini saling berkaitan. Berdasarkan uraian diatas, peneliti menyimpulkan bahwa kesesuaian tahapan perkembangan pada anak usia prasekolah dipengaruhi oleh banyak sekali faktor yang bisa membuat kenapa perkembangan anak bisa dikatakan sesuai, meragukan dan menyimpang. Pada penelitian ini karena pemantauan perkembangan anak dilakukan secara mandiri oleh orang tua sejak adanya pandemi Covid-19 yang memungkinkan terjadinya banyak sekali perbedaan pemahaman terhadap cara mengukur tingkat perkembangan anak. Instrumen yang kami gunakan adalah KPSP yang kami modifikasi dalam bentuk google form yang berisi tugas perkembangan sesuai usia anak. Sehingga memunculkan banyak variasi dalam kategori perkembangan responden penelitian.

\section{Hubungan Stimulasi Orang Tua dengan Perkembangan Anak Usia Prasekolah selama Pandemi Covid-19}

Berdasarkan hasil uji statistik menggunakan uji korelasi spearman rank dapat diketahui bahwa antara stimulasi orang tua dengan perkembangan anak didapatkan nilai signifikansi sebesar 0,203 ( $p$ value $>0,05$ ), yang artinya tidak terdapat hubungan signifikan antara stimulasi orang tua dengan perkembangan anak prasekolah selama masa Pandemi Covid-19. Hal ini tentunya banyaknya faktor yang mempengaruhi terhadap adanya hasil penelitian tersebut.

Faktor yang mempengaruhi stimulasi ada beberapa hal diantaranya keadaan sosial ekonomi, keluarga, kesehatan, dan kemampuan dasar individu. Selain itu stimulasi ini juga tergantung dari berapa lama, kapan awal stimulasi diberikan dan cara melakukan stimulasinya. Adapun ciri khas perkembangan anak antara lain terjadi secara berurutan dan pola perkembangannya tetap, sehingga pemberian stimulasi awal harus terarah. Stimulasi yang diberikan disarankan untuk membentuk kemampuan dasar sebelum mengembangkan kemampuan periilaku dan kognitif-akademik yang lebih kompleks (Suryawan, A, 2010).

Menurut hasil penelitian yang dilakukan oleh peneliti pada anak usia 3672 bulan, orang tua melakukan stimulasi motorik kasar berupa mengajak anak berlari, sepak bola, lempar bola, berjalan melatih keseimbangan, melompat dengan satu kaki dengan bermain engklek atau lompat tali, sedangkan motorik halus dengan mengajak bermain puzzle, menggunting, kolase, mewarnai, berhitung, menurutkan angka, dan memasak. Stimulasi bahasa dengan membaca buku cerita, menyanyi, bercerita dan sosialnya dengan mengajak anak makan dan bermain diluar dengan teman sebaya. Papalia, Olds dan Feldman dikutip (Mulqiah et al., 2017) menyatakan perkembangan bahasa dipengaruhi oleh faktor internal dan eksternal dimana yang termasuk faktor internal adalah persepsi, kognisi, dan prematuritas dan yang termasuk dalam faktor eksternal adalah riwayat keluarga, pola asuh, lingkungan verbal, pendidikan, dan jumlah anak, perkembangan fisik motorik dengan mengajak anak senam, 
bersepeda, menempel, melompat, berlari, bersembunyi, perkembangan nilai agama dan moral menulis huruf hijaiyah, membaca doa sehari-hari, shalat bersama, perkembangan sosial emosional bermain masak-masakan, berjualan mobil-mobilan, sepak bola, bermain petak umpet, perkembangan kognitif dengan menghitung jumlah bola, berhitung, mengelompokkan mainan.

Dari penelitian ini diperoleh bahwa stimulasi yang diberikan orang tua terhadap anak usia 0- 6 tahun di masa pandemi covid-19 di rumah termasuk dalam kategori cukup sebesar $81,3 \%$ dengan memiliki keberagaman berupa latihan-latihan rangsangan perkembangan dari orang tua. Stimulasi yang diberikan mengajak anak untuk bercerita, bermain di pekarangan rumah, membacakan buku cerita, mewarnai bersama, mendampingi anak dalam mengerjakan tugas sekolah, beribadah bersama ayah dan ibu di rumah. Sedangkan perkembangan anak usia prasekolah diperoleh sebagian besar sejumlah $80 \%$ perkembangannya sesuai. Perkembangan sesuai usia pada anak yang dinilai dengan instrument KPSP secara online melalui google form oleh orang tua

\section{KESIMPULAN DAN SARAN}

Hasil penelitian menunjukkan bahwa sebagian besar stimulasi orang tua anak usia prasekolah selama Pandemi Covid-19 di TK Insan Permata adalah cukup sebanyak 122 responden (81, 3\%). Hasil penelitian menunjukkan bahwa sebagian besar perkembangan anak usia prasekolah selama Pandemi Covid-19 di TK Insan Permata 120 (80\%) memiliki perkembangan yang sesuai. Berdasarkan hasil uji statistik menggunakan uji korelasi spearman rank dapat diketahui bahwa antara stimulasi orang tua dengan perkembangan anak didapatkan nilai signifikansi sebesar 0,203 ( $p$ value $>0,05$ ), yang artinya tidak terdapat hubungan signifikan antara stimulasi orang tua dengan perkembangan anak prasekolah selama masa Pandemi Covid-19 karena masing-masing. Pencapaian perkembangan anak ini tentunya tidak terlepas selain peran dari orang tua namun juga peran pendidik ketika masih sebelum pandemi Covid-19 serta PBM online selama pandemi Covid19.

Hasil penelitian menyatakan tidak terdapat hubungan yang signifikan dari stimulasi orang tua dan perkembangan anak bukan berarti bahwa stimulasi orang tua tidak perlu dikembangkan dalam meningkatkan perkembangan anak, namun lebih ke arah kita harus melihat secara luas dari stimulasi tersebut misalnya jenis stimulasi apa yang diberikan , berapa lama dan seberapa sering pemberian stimulasi tersebut, dan metode atau bagaimana cara melakukan stimulasi serta ketepatan alatalat apa yang digunakan untuk melakukan stimuasi tersebut. Selain stimulasi terkait perkembangan anak, ada banyak faktor yang mempengaruhi perkembangan anak baik dari faktor internal maupun faktor eksternal, faktor internal meliputi ras, keluarga, umur dan jenis kelamin sedangkan faktor eksternal meliputi selama persalinan, prenatal dan pasca persalinan sehingga bisa menjadikan faktor bias dalam hasil penelitian ini.

banyak faktor internal dan eksternal yang mempengaruhinya.

Pemantauan terhadap Perkembangan Anak usia Prasekolah dengan menggunakan instrument KPSP ini harapannya bisa dilakukan secara berkelanjutan dan bisa dikombinasi dengan instrument pengukuran perkembangan anak yang lainnya misalnya DDST dll. Instrumen ini bisa dilakukan kombinasi sesuai dengan kondisi responden. Penelitian sebaiknya dilakukan secara offline bukan secara online untuk mendapatkan hasil yang maksimal sesuai dengan kompetensi profesi yang melakukan pengukuran perkembangan anak, jikapun online harus ada kunjungan rumah untuk memastikan kebenaran jawaban dari pengisian dan pengukuran menggunakan KPSP. 


\section{DAFTAR PUSTAKA}

Adriana, D. 2017. Tumbuh Kembang dan Therapy Bermain pada anak. Jakarta:

Grover D, 2015. Partnering with Families: Improving Home Visits in Europe and Central Asia. Dalam A Good Start: Advance in Early Childhood Development. Bernard van Leer Foundation. Diakses dari www.bernardvanleer.org. Diunduh pada tanggal 14 November 2015

Kementerian Kesehatan, RI, 2016. Pedoman Pelaksanaan Stimulasi, Deteksi dan Intervensi Dini Tumbuh Kembang Anak Ditingkat Pelayanan Kesehatan Dasar. Jakarta: Departemen Kesehatan RI.

Kemenkes RI, 2018. Profil Kesehatan Indonesia tahun 2018. Jakarta.

Maryani K, 2020. Penilaian dan Pelaporan Perkembangan Anak saat Pembelajaran di Rumah di Masa Pandemic Covid-19. Jurnal Pendidikan Anak Usia Dini, vol 1. No 2, Juli 2020: Banten
Mitayani Y, Riska N \& Nursetiawati S. 2015. Hubungan Stimulasi Ibu dengan Perkembangan Motorik pada Anak Usia 2-3 Tahun (TODDLER). Jurnal Kesejahteraan Keluarga dan Pendidikan, Vol 4. No 1, April 2015: Jakarta

Sulistyawati, A. 2015. Deteksi Tumbuh Kembang Anak. Jakarta: Salemba Medika.

Suci HF, Lestari P. 2016. Pengaruh pemberian stimulasi pada perkembangan anak usia 12-36 di Kecamatan Sedayu, Bantul. JNKI. 4(1):44-8.

Soetjiningsih \& Ranuh, 2016. Tumbuh kembang anak. Edisi 2: buku Kedokteran, Jakarta; EGC.

Sumiyati, Yuliani DR. 2016. Hubungan stimulasi dengan perkembangan anak usia 4-5 tahun di desa karangtengah kecamatan baturraden kabupaten banyumas. LINK. 12(1):34-38.

Nursalam, 2016. Konsep dan Penerapan Metodologi penelitian ilmukeperawatan. Jakarta: Salemba. 